\title{
PRESUPPOSITION IN THE JAKARTA POST'S POLITICAL ARTICLES: A PRAGMATICS APPROACH
}

\author{
Fahrus Zaman Fadhly \\ Department of English Education, University of Kuningan, Indonesia \\ E-mail: fahruszf@gmail.com \\ Ayu Putri Kurnia \\ Department of English Education, University of Kuningan, Indonesia \\ E-mail: ayuputri031@gmail.com
}

APA citation: Fadhly, F. Z. \& Kurnia, A. P. (2015). Presupposition in The Jakarta Post's political articles: A pragmatics approach, 1(1), 117-124

\begin{abstract}
This study is aimed to investigate presupposition in The Jakarta Post daily newspaper's articles in political column. It covers two problems: types of presupposition and triggers of presupposition. Those problems were identified by applying presupposition theory. The data were interpreted by using descriptive qualitative method since it intended to describe a large number of sentences, clauses and phrases rather than numbers. The result of the study showed that the most frequent was existential presupposition with 202 occurences (78.59\%), followed by factive presupposition with 2 occurences $(0.79 \%)$, lexical presupposition with 36 occurences (14\%), structural presupposition with 11 occurences (4.28\%), non-factive presupposition with 2 occurences $(0.79 \%)$ and counterfactual presupposition with 4 occurrences $(1.56 \%)$. Besides, the study also showed the existence of 691 presupposition triggers which consisted of 631 definite descriptions (90.92\%), 2 factive items $(0.28 \%)$ which was similar to the existence of change of state verbs, 6 implicative verbs (0.86\%), 6 itteratives $(0.86 \%), 21$ temporal $(3.02 \%), 13$ comparisons and contrast $(1.87 \%), 8$ questions $(1.15 \%)$ and 3 counterfactual conditionals $(0.43 \%)$. Finally, the findings showed that both types and triggers of presuppositions were related each other.

Keywords: presupposition, types of presupposition, triggers of presupposition, political column, The Jakarta Post.
\end{abstract}

\section{INTRODUCTION}

This study investigates types of presupposition and their triggers in The Jakarta Post's political articles online edition. The reason for choosing the topic because the role of presupposition is important in the society especially in the area of advertising. It creates a point that the use of presupposition can be a basic theory in making some advertisements to become more interesting. Yingfang (2007, p. 55) mentions presupposition "as a very important in linguistics, especially in pragmatics, presupposition is frequently employed in order to enhance the effects of persuasion in advertisements because of its own special properties." It means that the presupposition has a unique thing to explore that aims to get people's interest toward the product which is promoted by some advertising company. Besides, people are going to have attention to the product since there is the relationship between presupposition and advertising language. According to Yingfang (2007, p. 55), "there exist some relations between presupposition and advertising language." In brief, the advertising language can be captured well using presupposition in order to make a good 
advertisement which aims to persuade consumers.

Meanwhile, Yule (1996, p. 25)

defines that "presupposition is something the speaker assumes to be the case prior to making an utterance". He argues that the speaker has assumption when s/he speaks about something, and the assumption is known by the hearers. It can be understood that the speaker and the hearer are sharing knowledge each other in a conversation. Yule (1996, p. 26) also mentions that "in many discussion of the concept, presupposition is treated as a relationship between two propositions". So, that means presupposition can occur when there exist two propositions which related each other.

Presupposition which is one of the pragmatics terms has the distinction. The distinction between presupposition and another pragmatics' theory is that presupposition will remain constant if the statement is negated, this situation is called constancy under negation (Yule, 1996, p. 26). As found in the example 'Everybody doesn't know that John is a gay,' even the statement is negated, the presupposition is still true and same, John is a gay.

Investigating types of presupposition in The Jakarta Post's articles online edition is inspired by several previous studies, i.e.: 'An analysis of Presupposition Triggers in English Journalistic Texts' by Khaleel (2010) and 'Presupposition Triggers: A Comparative Analysis of Broadcast News Discourse' by Zare (2007).

The phenomenon of presupposition is identified by Khaleel (2010) by investigating the main presupposition triggers in six selected English newspapers, i.e.: The Independent, The Guardian, The Daily Mirror, Liverpool Echo, The Belfast
Telegraph and The Northern Echo. Khaleel (2010, p. 523) mentions that "the analysis of the data has shown that English journalistic texts rely heavily on existential presupposition (definite descriptions) whose ratio has constituted $57.7 \%$ of the studied sample." So, the point is that the result of the study showed that existential presupposition which is triggered by definite description is mostly appeared in the texts since the occurance is the highest percentage of all.

The role of presupposition has been proven also by Zare (2012). According to Zare (2012, p. 734), "presuppositon has been used as a property of language to mold the audience's ideology." It means that the importance of presupposition cannot be denied as a part of communication whose function is to catch the readers' interests and the hearers as well. He believes that applying theory of presupposition can make the utterances more interesting to be read or listened. Zare (2012) identified triggers of presupposition in PressTV and CNN's transcript. He stated that both in PressTV and CNN's transcript, the number of existential triggers stand in the highest rank of all. He also noted that the frequency of existential trigger means entities and it is the simple one to making utterances to be more meaningful and understandable in giving information to the readers and listeners.

On the basis of the background to the studies above mentioned, this study investigates types of presupposition in articles of The Jakarta Post online edition. This study investigates the main presupposition and the triggers as well in The Jakarta Post' political articles online edition which are focused on political column. The Jakarta Post has been choosen as an object of the study since The Jakarta 
Post is the daily English Newspaper in Indonesia which has won several awards and been described as being "the Indonesia's leading Englishlanguage daily newspaper."

\section{METHOD}

The present study is largely using qualitative research design. In qualitative research method, the data taken from many texts are explored and analyzed using descriptive qualitative method since it intends to identify clauses, sentence and will be interpreted into the form of words rather than numbers (Frankel \& Wallen, 1990; Lincoln \& Guba, 1985; Meriam, 1988 in Creswell, 2009, p. 195).

Similarly, Alwasilah (2000) states that in the process of interpreting the data, it can be collected and interpreted specifically and contextually. Thus, this study uses descriptive qualitative method in interpreting the data since it mainly focuses on identifying the types and triggers of presuppositions. So that, the data should be shown in the form of word rather than numbers.

The main data sources in this study are the articles taken from The Jakarta Post online edition downloaded on February and June 2014. While the supporting data are taken from some books and references.

The articles are selected from The Jakarta Post's online edition using purposive sampling. Sugiyono (2012) defines that sampling purposive is the data selected can be setted up into the needs of study. This study applies 7 articles about political issues which put on the most viewed and most commented column in The Jakarta Post online edition. The selected articles are identified and classified into types of presupposition which consist of existential, factive, lexical, structural, non-factive and counter factual presupposition (Yule, 1996).

There are some stages in identifying the 7 selected articles in The Jakarta Post online edition. First, identifying the data into types of presupposition using the theory as proposed by Yule (996). Second, classifying and analyzing the selected data. Third, counting the number of presupposition for each type. Fourth, interpreting the data based on the findings.

\section{RESULTS AND DISCUSSION}

The result study shows that the most frequent presupposition is existential with 202 occurrences (78.59\%), followed by factive presupposition with 2 occurrences $(0.79 \%)$, lexical presupposition with 36 occurrences (14\%), structural presupposition with 11 occurences (4.28\%), non-factive presupposition with 2 occurrences $(0.79 \%)$ and counterfactual presupposition with 4 occurences (1.56\%). Example of existential presupposition:

[\#001] Our election campaign theme is "real work". (The Jakarta Post, 2014, February 24)

In the example above, the existential presupposition is indicated in the use of possesive construction 'Our' and Noun Phrase'election campaign theme.' Those definite descriptions indicated the existence of a group of people which was represented by the speaker. Besides, it also presupposed that a group of people had the theme for their campaign which was named 'real work'. Thus, the example [4a] contained more than one presupposition.

Factive presupposition occurs 2 times $(0.79 \%)$. Factive presupposition can be triggered by using verb like 'know' and it must be treated as a fact 
(Yule, 1996, p. 27). This following statement is the example of factive presupposition:

[\#002] So we don't know why the KPI has issues with our ads. (The Jakarta Post, 2014, February 27)

The data above is presented in negative form which is triggered by word 'know'. As a matter of fact, it presupposed that the KPI has issues with our ads. Although the data change into 'so we know why the KPI has issues with our ads', it does not affect the presupposition. It will remain constant that the KPI has issues with our ads.

Lexical presupposition occurs 36 times (14\%) in The Jakarta Post articles. Levinson (1997) explained that lexical presupposition could be symbolized by word like 'manage'. The word 'manage' indicates someone tries to do something. Thus, lexical presupposition exist since it aims to presuppose someone is succesfully in doing something.The lexical presupposition are exemplified in the followingg statement below:

[\#003] We can no longer provide fuel subsidies in the form of price adjustments (The Jakarta Post, 2014, February 27)

As found in the explanation before about lexical presupposition, is that lexical presupposition contains the meaning which is implicitly communicated but not said. The data above is involved into lexical presupposition since the word 'no longer' presupposes that we provide fuel subsidies in the form of price adjustments before.

Other type of presuppositions which are found in Jakarta Post is structural presupposition. This type is indicated by the use of wh-word in generating the information and it should be accepted 'true' by the hearers (Yule, 1996:28). Look at the examples below:

[\#004] What is PAN's view on the current education system? (The Jakarta Post, 2014, February 24)

The use of wh-word 'what' is used by speaker. When the speaker asked to the representative of the PAN party, s/he already had assumption about the information that they were going to talk about, that was about PAN's view on the current education system. It presupposes that PAN party has view relating to the education in Indonesia.

Non-factive presupposition occurs 2 times $(0.79 \%)$. Yule (1996) explained that non factive presupposition can be triggered by the words 'dream', 'imagine' and 'pretend'. As found in the example below:

[\#005] Presidential candidate Prabowo Subianto told his supporters on Wednesday not cast their votes for a leader who pretended to be a populist and who tended to break promises. (The Jakarta Post, 2014, June 12)

Based on the data [4i], the triggers on the statement indicates that the statement is not true with the condition in reality but it is communicated indirectly. In the data above mentioned, the word 'pretended' presupposes that a leader whom is told by Presidential candidate Prabowo was not be a populist in fact.

In The Jakarta Post, the counterfactual presupposition occurs 4 times $(1.56 \%)$. It can be implied by the word 'if' that presupposes the meaning. In counterfactual, what the speakers say presupposes not only untrue condition 
but also the opposite (contrary), as shown in the example below:

[\#006] [it] would be regarded as campaigning, and therefore must be banned if aired outside the campaign period. (The Jakarta Post, 2014, June 12)

The triggers 'if' presupposes that the information is contrary with the reality. It presupposes that the campaign is not doing in the outside campaign period. So that the campaign is allowed.

Besides, the study also shows the existence of 694 presupposition triggers which consist of 631 definite descriptions (90.92\%), 2 factive item $(0.28 \%)$ which is similar to existence of change of state verbs, 6 Implicative verbs $(0.86 \%), 6$ Itteratives $(0.86 \%), 21$ Temporal (3.02\%), 13 Comparison and Contrast (1.87\%), 8 questions $(1.15 \%)$ and 3 counterfactual conditionals $(0.43 \%)$. Examples of definite description are presented below:

[\#007] In his remarks at the party's call for readliness at the Bung Karno Stadiumin Senayan, Central Lakarta, on Sunday, Surya said corruption was rampant in Indonesia and was widespread in every sector. (The Jakarta Post, 2014, February 24)

Yule (1996) explained that the presupposition can be triggered not only in a possesive constructions but also in the definite noun phrases. There might be more than one noun phrase in a sentence or utterance. The underlined words above are the examples of noun phrases which were found in selected data. The use of definite descriptions indicated the entities; the existence of remarks, party's call, the Bung Karno
Stadium, Senayan, Central Jakarta and Surya.

The factive items can be treated as a fact, it can be words such as regret, aware, realize, know, be sorry that, be proud that, be different that, and be sad that (Kiparasky \& Kiparsky, 1997 in Levinson, 1983). The factive item which was found in The Jakarta Post's articles was exemplified as follow:

[\#008] So we don't know why the KPI has issues with our ads, he said. (The Jakarta Post, 2014, February 27)

Concerning the theory of presupposition, even the statement above was negated, the word 'know'still indicated the fact that the KPI has issues with the advertisements.

Other type of trigger is

Implicative verbs. Yule (1996) stated the word which was involved into types of implicative verb such as 'stop', 'start', 'again'. Meanwhile, (Kartuneen, 1971b in Levinson, 1983, p. 181) mentioned that 'forget', 'happened' and 'avoid' are the example of implicative verbs. Based on the theories, the implicative verbs that were found in articles such as avoid, start, again, manage. This statement below is one of the data in articles which containt an implicative verb:

[\#009] Weeks before the presidential campaign was due to kick off on June 5the supporters of both candidates started to question the opposing candidate's "level of Islam" (The Jakarta Post, 2014, June 12).

The word 'before' and 'started' on the statement above were the example of implicative verbs in article which presupposed that the supporters of both candidate did not ask about the 
opposing candidate's level of Islam before that weeks.

In The Jakarta Post articles, there is found change of state verbs also. The words 'stop', 'begin', continue, start, finish, carry on, cease, take, leave, enter, come, go and arrive are the example of Change of State verbs which are stated by Khaleel (2010:513). For example:

[\#010] To anticipate potential clashes between political parties, he said the KPU would continue coordinating with local elections commissions (KPUDs) and local branches of political parties to find the most suitable locations for outdoor gatherings of party supporters (The Jakarta Post, 2014, February 27).

The word 'continue' as a change of state verb on the statement above presupposed that the KPU had been coordinating with local election commissions (KPUDs) and local branches of political parties to find the most suitable locations for outdoor gatherings of party supporters.

The other triggers which are found in The Jakarta Post's articles online edition are repeatedly, repeat, again, another. Those words are categorized into itteratives which is treated that something is being repeated. This following statement is containing itterative:

[\#011] In Ogan Komering Ulu (OKU) regency, South Sumatra, a joint team comprising the local Elections Supervisory Committee (Panwaslu), the police and the Public Order Agency (Satpol PP), has repeatedly taken down campaign billboards and banners violating election regulations. (The Jakarta Post, 2014, February 27)

The trigger 'repeatedly' on the statement above presupposed that campaign billboards and violating election regulations had been taken down by a joint team comprising the local Elections Supervisory Committee (Panwaslu) and the police and the Public Order Agency (Satpol PP) more than one time.

Verbs like judging was exemplified in the statement of Agatha accused/didn't accused Ian of Plagiarism (Wilson, 1975 in Levinson 1983, p. 182). The trigger 'accuse' on that statement presupposed that Agatha thinks Plagiarism is bad. Meanwhile, the example of verbs like judging which was found in article as follow:

[\#012] Bawaslu commissioner Endang W., who filed the report on last August, accused the two of violating the Article 276 of the 2012 Legislative Election Law, carrying a maximum penalty of one year in jail and a Rp 12 million (US\$1,032) fine. (The Jakarta Post, 2014, February 27)

The use of verb 'accused'indicated Bawaslu comissioner Endang thinks that carrying a maximum penalty of one year in jail and a $\mathrm{Rp} 12$ million (US\$1,032) fine is bad.

There are several words are involved into temporal clause such as before, while, since, after, during, whenever (Frege, 1982 in Levinson 1983, p. 182). Similarly, in The Jakarta Post's articles are found the numbers of temporal clauses as found in the example below:

[\#013] During the campaign, Anis Matta told the audience to vote for 
Prabowo because of the latter's handsome appearance (The Jakarta Post, 2014, June 12).

The trigger 'during the campaign' on the statement above presupposed that Anis Matta told the audience to vote for Prabowo. Another temporal clauses which were found in The Jakarta Post article were since, before, after, and while.

Other presupposition trigger

which is found in The Jakarta Post is Comparisons and contrasts. There exist comparative constructions such as most important, more than, fewer, smaller.

[\#014] The most important thing now is to ensure that human rights violations do not take place in the future by establishing a tolerant and moderate society (The Jakarta Post, 2014, February 24).

The underlined words above is considered as a trigger comparative construction which was implied by the word 'most' which presupposed that ensuring human rights violations do not take place in the future is the most important thing.

The trigger Questions also occur in Jakarta Post articles which are implied by the word wh-questions (who, what, why, when or how. This statement below is the example of trigger question:

[\#015] How will PAN handle foreign statements? (The Jakarta Post, 2014, February 24).

The presupposition of the statement above was PAN handle foreign investments since it was containing the trigger 'How' in the statement. It means that the speaker on the statement was already known that PAN handle foreign investments. They (speaker and hearers) were sharing knowledge each other.

The last trigger is counterfactual presupposition which is triggered by the word 'if'. It presupposes the contrary or it's not true condition. Here is the example:

[\#016] If they fail to fulfill this requirement, then we will not pay them (The Jakarta Post, 2014, February 24).

Concerning the word if on the statement above, it presupposed that they actually did not fail to fulfill the requirement.

\section{CONCLUSION}

This study examines the types and triggers of presupposition in The Jakarta Post's articles online edition in political column. The result study shows that the most frequent presupposition is existential with 202 occurrences (78.59\%), followed by factive presupposition with 2 occurrences $(0.79 \%)$, lexical presupposition with 36 occurrences (14\%), structural presupposition with 11 occurences (4.28\%), non-factive presupposition with 2 occurrences $(0.79 \%)$ and counterfactual presupposition with 4 occurences $(1.56 \%)$.

Besides, the study also shows the existence of 694 presupposition triggers which consist of 631 definite descriptions (90.92\%), 2 factive item $(0.28 \%)$ which is similar to the existence of change of state verbs, 6 Implicative verbs $(0.86 \%), 6$ Itteratives (0.86\%), 21 Temporal (3.02\%), 13 Comparison and Contrast (1.87\%), 8 questions $(1.15 \%)$ and 3 counterfactual conditionals $(0.43 \%)$.

Based on the findings mentioned earlier, it can be concluded that types of presupposition were 
influenced by the presupposition triggers. Both the types and the presupposition triggers are related each other for instances, the existential presuppositions triggered by the definite descriptions; they are standing in the highest percentage of all. It means that the writer of The Jakarta Post's political column used the entities of person, something, problems, things in conveying the information about politics to the readers. As been stated in the previous chapter, it might be showed in the noun of phrases, possesive constructions and some other definite descriptions.

\section{REFERENCES}

Alwasilah, A. C. (2002). Pokoknya kualitatif: Dasar-dasar merancang dan melakukan penelitian kualitatif. Jakarta: PT Dunia Pustaka Jaya

Beaver, I. D. (1997). Presupposition and assertions in dynamic semantics: California: Standford University.

Grundy, P. (2000). Doing pragmatics. New York: Oxford University Press.

Jong, H. N. (2014, February 28). KPU sets rules for April election campaign. The Jakarta Post. Retrieved from http://www.thejakartapost.com/news/ 2014/02/28/kpu-sets-rules-aprilelectioncampaign.html\#sthash.yGYGqCJW.dpuf

Jong, H. N. and Perdani, Y. (2014, February 27). Parties banned from running campaign ads. The Jakarta Post. Retrieved from http://www.thejakartapost.com/news/ 2014/02/27/parties-banned-runningcampaignads.html\#sthash.i48XmUwL.dpuf

Khaleel, L. M. (2010). An analysis of presupposition triggers in English journalistic text. Journal of College of Education For Women, 21(2), 523-551.

Levinson, S. C. (1983). Pragmatics. Cambridge: Cambridge University Press.

Paloh, P. (2014, February 24) Surya Paloh highlights corruption issue. The Jakarta Post. Retrieved from http://www.thejakartapost.com/news/ 2014/02/24/surya-paloh-highlights- corruption-

issue.html\#sthash.9u7Sia0n.dpuf.

Rajasa, H. (2014, February 24). Our election strategy tagline is 'real work': Hatta. The Jakarta Post. Retrieved from http://www.thejakartapost.com/news/ 2014/02/28/our-election-strategytagline-real-workhatta.html\#sthash.nSDVsuST.dpuf

Renkema, J. (2004). Introduction to discourse studies. Philadelphia: John Benyamin Publishing Company

Saeed, J..I. (1997). Semantics. Oxford: Blackwell Publishers, Ltd.

Subianto, P. (2014, June 12). Prabowo, Jokowi trade barbs. The Jakarta Post. Retrieved from http://www.thejakartapost.com/news/ 2014/06/12/prabowo-jokowi-tradebarbs.html\#sthash.6dJFfqQ2.dpuf.

Sugiyono (2011). Metode penelitian kuantitatif, kualitatif dan $R \quad \& \quad D$. Bandung: Alfabeta.

Yingfang, W. (2007). Analysis of presupposition and its function in advertisement. Canadian Social Science, 3(4), 55-60.

Yule, G. (1996). Pragmatics. Oxford: Oxford University.

Zare', J., A. Ehsan., Nia, M. R. (2012). Presupposition trigger-a comparative analysis of broadcast news discourse. International Journal of Linguistics, 4(3), 734-743. 